\title{
Is hatching success of copepod eggs diatom density-dependent?
}

\author{
Yannick Chaudron ${ }^{1}$, Serge André Poulet ${ }^{1, *}$, Mohamed Laabir ${ }^{1}$, Adrianna Ianora ${ }^{2}$, \\ Antonio Miralto ${ }^{2}$
}

${ }^{1}$ Station Biologique de Roscoff, Place G. Teissier, CNRS, F-29682 Roscoff, France

${ }^{2}$ Stazione Zoologica 'A. Dohrn', Villa Communale, I-80121 Napoli, Italy

\begin{abstract}
Two species of diatoms, Phaeodactylum tricornutum and Thalassiosira rotula, were fed to Calanus helgolandicus females at concentrations varying between 10 and $10^{6}$ cells $\mathrm{ml}^{-1}$. Their effects on the fecundity and hatching success of eggs were compared with those of the dinoflagellate diet Prorocentrum minimum at $10^{4}$ cells $\mathrm{ml}^{-1}$ used as a control. Specific maximum fecundity was never reached with the diatom diets. The paradox is that fecundity and inhibition of hatching were diatom densitydependent, but varied in opposite directions in relation to concentration. At high diatom concentrations ( $\mathrm{ca} \geq 10^{3}$ cells $\mathrm{ml}^{-1}$ ) fecundity increased, whereas hatching was totally inhibited. At low concentrations ( $\mathrm{ca} \leq 10^{3}$ cells $\mathrm{ml}^{-1}$ ), resembling in situ conditions, fecundity was depressed while hatching success values were generally below $70 \%$ or showed high amplitude variations. Inhibition of hatching was proportional to fecal pellet production rate, reflecting the causal relation between ingestion, duration of feeding and accumulation of the inhibitor. The inhibitory mechanism was best fitted by a logistic function of time, the parameters of which were significantly modified for diatom concentrations $\geq 10^{3}$ cells $\mathrm{ml}^{-1}$ These results suggest that ingestion of diatoms might be considered as one of the causes limiting $C$. helgolandicus population recruitment in nature, since both fecundity and hatching can be significantly lowered at low and high diatom concentrations, respectively.
\end{abstract}

KEY WORDS: Copepod · Calanus helgolandicus - Diatoms · Inhibition

\section{INTRODUCTION}

High mortality in copepods has been shown to occur mainly in the earliest phases of development. Of the 12 developmental stages, nauplii appear to be the most sensitive, suffering a higher mortality than copepodites and adults (Confer \& Cooley 1977, Dagg 1977, Williamson et al. 1985, Santer 1994). Also, the embryonic stage is subject to high mortality with up to $60-70 \%$ loss of eggs in certain periods of the year (Kiørboe et al. 1988, Ianora et al. 1992, Laabir et al. 1995b).

In the field, one major cause of mortality is assumed to be predation (Kiørboe \& Nielsen 1994, Liang et al. 1994, Peterson \& Kimmerer 1994). In the laboratory, mortality of embryos and nauplii has been related to the starvation of adults and juveniles as well as to food

-Addressee for correspondence. E-mail: poulet@sb-roscoff.fr characteristics such as the deficiency of certain essential nutrients, influencing egg sizes and thus, indirectly, egg viability (Dagg 1977, Jónasdottir 1994, Santer 1994, Guisande \& Harris 1995). Other potential factors affecting mortality of juveniles have been suggested (such as virus and disease, genetic disorders, low fitness and pollution; Toudal \& Riisgard 1987, Peterson \& Kimmerer 1994).

Recent investigations have shown that ingestion of diatoms by adult copepod females, fed ad libitum, was followed by low hatching success, abnormal embryonic development or naupliar anomalies (Poulet et al. 1994, 1995, Ianora et al. 1995). Mortality was due to the presence of an unidentified diatom factor blocking or disrupting normal embryonic development. Inhibition of development was $100 \%$ when the concentration of diatoms in copepod diets was $\geq 10^{4}$ cells $\mathrm{ml}^{-1}$. The rate of mortality related to diatom inhibitors was assumed to be diatom density- and time-dependent (Laabir et al. 
1995b, Poulet et al. 1995). The inhibitor concept implies that the higher the density of diatoms and the longer they are ingested by copepods, the lower the hatching success. It further implies that the lag time between the start of ingestion and the inhibitory response should increase when diatom density decreases. This hypothesis was considered unrealistic, since the highest density of diatoms in blooms occurring in nature is generally between 10 and $10^{3}$ cells $\mathrm{ml}^{-1}$, which is 2 to 4 orders of magnitucie lower than concentrations tested in the laboratory (lanora \& Poulet 1993 and subsequent studies). However, Laabir et al. (1995b) have shown that field estimates of hatching success in Calanus helgolandicus were on the average $70 \%$ over the year. It was seasonally unstable and often reached values $\leq 50 \%$, reflecting the diversity of food ingested by females, shifts in the diet and in situ concentration of diatoms characterising water conditions offshore of Roscoff (English Channel; Sournia \& Birrien 1995). These results have revealed that diatoms are a potential cause of mortality for copepods in nature, even though their impact, at times, was less than that under laboratory conditions. They also showed that a lag time of about 15 to $30 \mathrm{~d}$ might exist between peaks of diatom density and minimum values of hatching success.

The objective of the present work was to determine the variations of hatching success and the lag time preceding inhibition in relation to diatom density. Our aim was to. show that the inhibitor concept is realistic and might be useful to better understand recruitment of copepod nauplii in relation to naturally occurring diatom concentrations.

\section{MATERIALS AND METHODS}

Calanus helgolandicus females were collected twice a week from 7 March to 12 June 1995, offshore of Roscoff (France) and brought to the laboratory within 1 to $2 \mathrm{~h}$ of collection. There, batches of 10 to 25 females each were incubated in crystallizing dishes filled with filtered sea water $(0.22 \mu \mathrm{m})$ enriched with cultures of one of 3 different species of phytoplankton: the dinoflagellate Prorocentrum minimum (PM), and the diatoms Phaeodactylum tricornutum (PT) and Thalassiosira rotula $(\mathrm{TR})$, and taking carbon content equivalent to $6.8 \mathrm{pg} \mathrm{C} \mathrm{cell}{ }^{-1}$ for PT, $157 \mathrm{pg} \mathrm{C} \mathrm{cell}^{-1}$ for $\mathrm{TR}$ and $274 \mathrm{pg} \mathrm{C} \mathrm{Cell}^{-1}$ for PM (not included in the regression of Fig. 5). Duration of incubations varied between 10 and $45 \mathrm{~d}$. Concentration of phytoplankton in incubators was constant for PM $\left(10^{4}\right.$ cells $\left.\mathrm{ml}^{-1}\right)$, whereas for the 2 other algae, the concentrations ranged from $10^{4}$ to $10^{6}$ cells $\mathrm{ml}^{-1}$ for PT and from 10 to $10^{5}$ cells $\mathrm{ml}^{-1}$ for TR. At high PT concentrations (i.e. $10^{4}$ to $10^{6}$ cells $\mathrm{m}^{-1}$ ), incubators used for the experiments were crystallizing dishes filled with $200 \mathrm{ml}$ filtered sea water, each containing 10 to 12 females. Stirring of algae was done manually 3 to 5 times a day. At these concentrations, fecundity was high and a large number of eggs ( $\mathrm{n} \geq 100$ ) was sampled daily, allowing for an accurate estimation of hatching success. At lower concentrations (i.e. $\leq 10^{3}$ cells $\mathrm{ml}^{-1}$ ) the type of incubator had to be changed. First, because fecundity reached low values $\left(0 \leq n \leq 5\right.$ eggs female ${ }^{-1}$ $\mathrm{d}^{-1}$ ) in less than $6 \mathrm{~d}$; and second, because cannibalism of eggs was extremely severe. The problems of cannibalism at low food density and depression of fecundity have already been discussed by Laabir et al. (1995a). The new incubators were equipped with a $300 \mu \mathrm{m}$ size mesh partition and with a water circulating system (flow rate: $60 \mathrm{ml} \mathrm{min}{ }^{-1}$ ) so that cannibalism could be reduced and resuspension of food improved. Twenty to 25 females were added to each incubator, which was filled with 2 l of filtered sea water and enriched with known volumes of algal cultures. With TR, fecundity remained high enough during the entire incubation period at all concentrations between $10^{4}$ and $10^{2}$ cells $\mathrm{ml}^{-1}$, allowing a sufficiently large number of eggs ( $25 \leq$ $n \leq 200$ ) to be collected daily in samples and, thus, satisfactory statistical evaluation of hatching success. At 10 cells $\mathrm{ml}^{-1}$, hatching success could not be evaluated accurately, because fecundity was too low $(0 \leq n \leq$ 2 eggs female $e^{-1} \mathrm{~d}^{-1}$ ). During preliminary tests, we verified that algae were resuspended, while eggs were sedimented at the bottom of the new incubators. Incubation of females and eggs was made at constant room temperature $\left(12 \pm 0.5^{\circ} \mathrm{C}\right.$, corresponding to in situ temperatures at time of capture) and followed a natural day-night light cycle. Death of females 10 to $30 \%$ of initial numbers) occurred mainly towards the end of the incubation period ( $>25$ to $30 \mathrm{~d}$ ). However, dead females were never replaced by new ones. Filtered sea water and new algal food were replaced every day in each incubator Egg production, hatching success and fecal pellets were evaluated in samples collected daily. Pellets were counted in triplicates in each incubator containing $\mathrm{PT}$ at concentrations ranging from $10^{3}$ to $10^{6}$ cells $\mathrm{ml}^{-1}$, and TR at $10^{4}$ cells $\mathrm{ml}$ : (control). About 25 to 200 eggs sample ${ }^{-1}$, grouped in batches of 25 to 40 each, were incubated $48 \mathrm{~h}$ in 1 to $2 \mathrm{ml}$ filtered sea water. All results are means (i.e. fecundity) and sums (i.e. hatching) for 3 series of replicated experiments. Algal cultures were grown in F/2 and K mediums (Guillard \& Ryther 1962, Keller et al. 1987) for diatoms and dinoflagellates, respectively. Comparisons between diets are also given in terms of $\mathrm{pg} \mathrm{C} \mathrm{Cell}^{-1}$, using values from the literature $(\mathrm{PM}=274, \mathrm{TR}=157$ and $\mathrm{PT}=6.8$; Saunders 1991, Ianora \& Poulet 1993). Curve fitting analysis and statistics were performed for each algal concentration, using the SYSTAT and Sigma plot programs (Wilkinson et al. 1992, Fox \& Shotton 1995). 


\section{RESULTS}

Variation with time of the fecundity of Calanus helgolandicus fed the 3 different diets was measured in parallel with hatching success in the same series of experiments (Fig. 1). Daily egg production rate was strongly influenced both by the type and the concentration of food. Comparison between controls (PM) and experiments ( $\mathrm{PT}$ and $\mathrm{TR}$ ) indicated that under laboratory conditions, fecundity was not influenced during the incubation period, so we assumed that the unknown age of the females could affect the responses of copepods in the same way. With the dinoflagellate PM, fecundity varied daily between 10 and 30 eggs female $^{-1}$ (Fig. 1A), and rarely fell below 10 eggs female $e^{-1} \mathrm{~d}^{-1}$. Fecundity had a different pattern when females were fed with diatoms. With PT, egg production rates ranged respectively between 1 and $6,0.5$ and 2,0 and 1 eggs female $e^{-1} \mathrm{~d}^{-1}$, decreasing as the concentration diminished (Fig. 1B), except for the first days of incubation. With TR, egg production was extremely variable (Fig. 1C). At $10^{5}$ and $10^{4}$ cells $\mathrm{ml}^{-1}$, fecundity shifted between low $\left(<10\right.$ eggs female $\left.{ }^{-1} \mathrm{~d}^{-1}\right)$ and high (up to 30 eggs female $\mathrm{e}^{-1} \mathrm{~d}^{-1}$ ) values. At lower concentrations (10 to $10^{3}$ cells $\mathrm{ml}^{-1}$ ) fecundity was between 0 and 10 eggs female ${ }^{-1} \mathrm{~d}^{-1}$, except for the first days of incubation, which reflected the past-feeding history of females.

With the control food PM, hatching success was extremely high and stable, remaining above $90 \%$ most of the time, except at the begining of the time series, at which lower values were observed for the first $4 \mathrm{~d}$ (Fig. 2). With this diet, a nonlinear regression equation was found between hatching success $\left(Y_{1}\right)$ and time $(X)$, given by the hyperbolic equation:

$$
Y_{1}=\frac{a_{1} X}{b_{1}+X}
$$

where $a_{1}$ is maximum hatching value and $b_{1}$ corresponds to the time at which hatching $=a_{1} / 2$. Values calculated for parameters $a_{1}$ and $b_{1}$ and statistics are given in Table 1.

In a new set of experiments, batches of females were fed the diatom Phaeodactylum tricornutum at 3 different concentrations. A first set of experiments testing the effect of high algal concentrations $\left(10^{6}\right.$ cells $\left.\mathrm{ml}^{-1}\right)$ was conducted for $12 \mathrm{~d}$ but was then interrupted because no hatching occurred after that period. During the first $6 \mathrm{~d}$ (Fig. 2), values decreased from 90 to $50 \%$, then decreased sharply down to $10 \%$ in $2 \mathrm{~d}$ and finally remained below $5 \%$ until the end of incubation. This succession of periods with high and low hatching values shows the complex reproductive response of copepods to this food. Hatching $\left(Y_{2}\right)$ was best fitted by a logistic function of time $(X)$, given by the sigmoid equation:
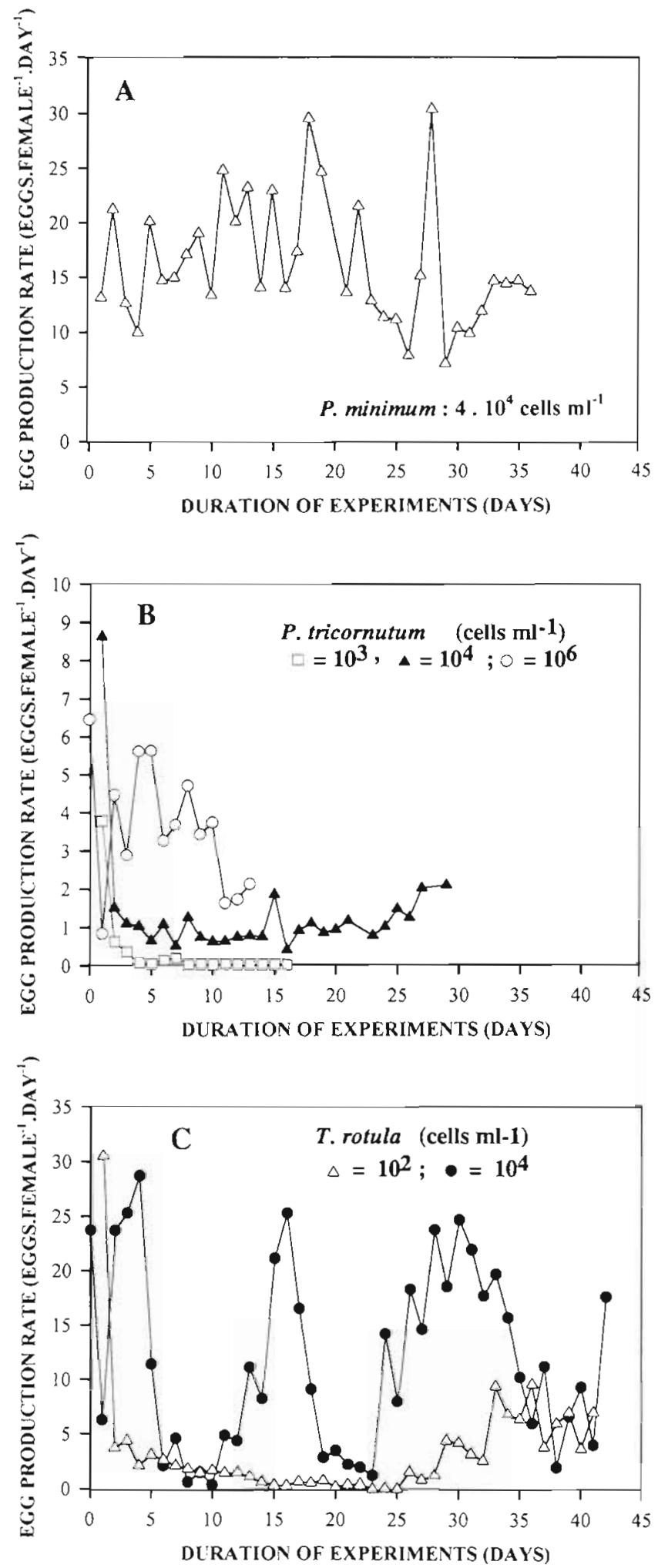

Fig. 1 Relationship between daily egg production rate of Calanus helgolandicus and the type and concentration of cells in diets. (A) Controls: PM at $10^{4}(\Delta)$ cells $\mathrm{ml}^{-1}$; (B) PT at $10^{3}$ $(\square), 10^{4}(\Delta)$ and $10^{6}(O)$ cells $\mathrm{ml}^{-1} ;(\mathrm{C}) \mathrm{TR}$ at $10^{2}(\Delta)$ and $10^{4}$ cells $\mathrm{ml}^{-1}$ Each data point is the mean of 3 experiments 


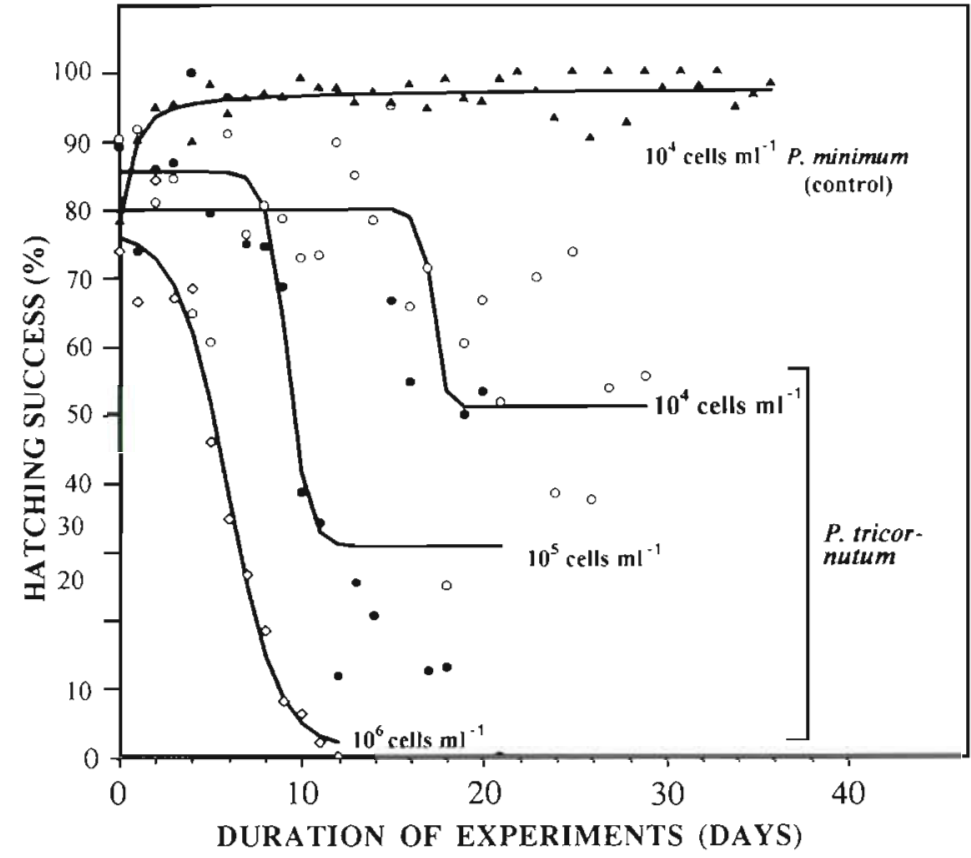

Fig. 2. Vanations in hatching success with time for Calanus helgolandicus females fed the diatom Phaeodactylum tricornutum (PT) at 3 concentrations: $10^{4}(0), 10^{5}(\bullet)$ and $10^{6}(\diamond)$ cells $\mathrm{ml}^{-1}$ Females in controls were fed the dinoflagellate Prorocentrum minimum (PM) at $10^{4}(\boldsymbol{\Lambda})$ cells $\mathrm{ml}^{-1}$ Each data point corresponds to the average of 3 experiments. Parameters of Eqs. (1) and (2) best fitting the data set for PM and PT, respectively, corresponding to each food concentration are given in the text and in Table 1 hatching values. Values estimated for fitted parameters $a_{2}$ to $d$ and statistics are given in Table 1.

A second set of experiments was conducted for $18 \mathrm{~d}$ with females fed the same diatoms at a concentration equal to $10^{5}$ cells $\mathrm{ml}^{-1}$ Variations in hatching success were again significantly fitted by the same equation (Eq. 2). The calculated range (a) between minimum and maximum hatching values had decreased, while the values calculated for the point of inflexion (c) and the lower threshold of hatching success ( $d$ ) had increased significantly with respect to the higher algal concentration (Table 1). In the third set of experiments, females were fed PT at even lower food concentration, equal to $10^{4}$ cells $\mathrm{ml}^{-1}$. The values followed the same pattern (Fig 3) and were also fitted by Eq. (2). As food concentration decreased, parameters a to $d$ were modified as well (Table 1). In this case, the range (a) was only $29 \%$. The slope (b) was strongly modified, whereas the values for $c$ and $d$ had almost doubled. At $10^{4}$ and $10^{5}$ cells $\mathrm{ml}^{-1}$, dispersion of hatching values was high, mainly during the second half of the incubations. The results (Fig. 2 , Table 1) show that hatching success varied with time when Calanus helgolandicus were fed the diatom. PT, at all concentrations.

$$
Y_{2}=\frac{a_{2}}{1+e^{b_{2}(X-c)}}+d
$$

where $a_{2}\left(=a_{\max }-a_{\min }\right)$ is the range of variation of the hatching success values, $b_{2}$ is the slope coefficient, $c$ is the time, in days, of the maximum rate of change (i.e. point of inflexion) and $d$ is the lower threshold of
Two orders of magnitude variations in food concentration induced significant modifications of parameters $a, b$ and $c$ in Eq. (2) by a factor of 3 to 6 . The most striking modifications were related to the decrease of both the lag time $(c)$ and lower threshold $(d)$ in relation to increasing diatom concentrations (Table 1).

Table 1. Variations of the values of parameters: $a$ (in Eq. 1, $a_{1}=$ maximum hatching values; in. Eq. $2, a_{2}=$ maximum range of hatching values) $; b$ (in Eq. $1, b_{1}=$ time at which half maximum value of hatching is reached in Eq. $2, b_{2}=$ slope coefficient) $c$ and $d$ (in Eq. 2, time corresponding to maximum rate of change in hatching, and lower threshold of hatching values, respectively, see text for details), in relation to the 3 algal diets $(\mathrm{PM}=$ Prorocentrum minimum; $\mathrm{PT}=$ Phaeodactylum tricornutum; $\mathrm{TR}=$ Thalassiosira rotula) and to different algal concentrations (number of cells $\mathrm{ml}^{-1}$ ) in the incubators. $\mathrm{n}$. number of observations; $\mathrm{r}^{2}$. coefficient of correlation; $\chi^{2}$ value of the $\chi^{2}$ test; df: degrees of freedom; significant at $\alpha \leq 0.05$

\begin{tabular}{|c|c|c|c|c|c|c|c|c|c|}
\hline $\begin{array}{l}\text { Algai } \\
\text { diet }\end{array}$ & $\begin{array}{l}\text { Concentration } \\
\left.\text { (cells } \mathrm{ml}^{-1}\right)\end{array}$ & $\mathrm{n}$ & $a_{1}$ & $b_{1}$ & & & $r^{2}$ & $x^{2}$ & $\mathrm{df}$ \\
\hline \multirow[t]{2}{*}{ PM } & $10^{4}$ & 37 & 97.4 & 0.08 & & & $0.98^{\circ}$ & $3.3^{\circ}$ & 36 \\
\hline & & & $a_{2}(\%)$ & $b_{2}$ (day) & $c($ day $)$ & $d(\%)$ & & & \\
\hline PT & $10^{6}$ & 13 & 75.9 & 0.73 & 5.93 & 1.19 & $0.97^{\circ}$ & $14.42^{\circ}$ & 12 \\
\hline PT & $10^{5}$ & 22 & 54.9 & 1.83 & 9.23 & 30.8 & $0.73^{\circ}$ & $27.26^{\circ}$ & 21 \\
\hline $\mathrm{PT}$ & $10^{4}$ & 28 & 28.9 & 6.79 & 17.1 & 51.2 & $0.61^{\circ}$ & $38.69^{\circ}$ & 27 \\
\hline TR & $10^{5}$ & 8 & 46.7 & 3.01 & 2.13 & 11.5 & $0.98^{\circ}$ & $5.27^{\circ}$ & 7 \\
\hline TR & $10^{4}$ & 39 & 19.9 & 2.65 & 7.54 & 63.8 & $0.24^{\circ}$ & 189.4 & 38 \\
\hline TR & $10^{3}$ & 44 & 16.1 & 1.67 & 22.3 & 64.8 & $0.35^{\circ}$ & 83.72 & 43 \\
\hline
\end{tabular}




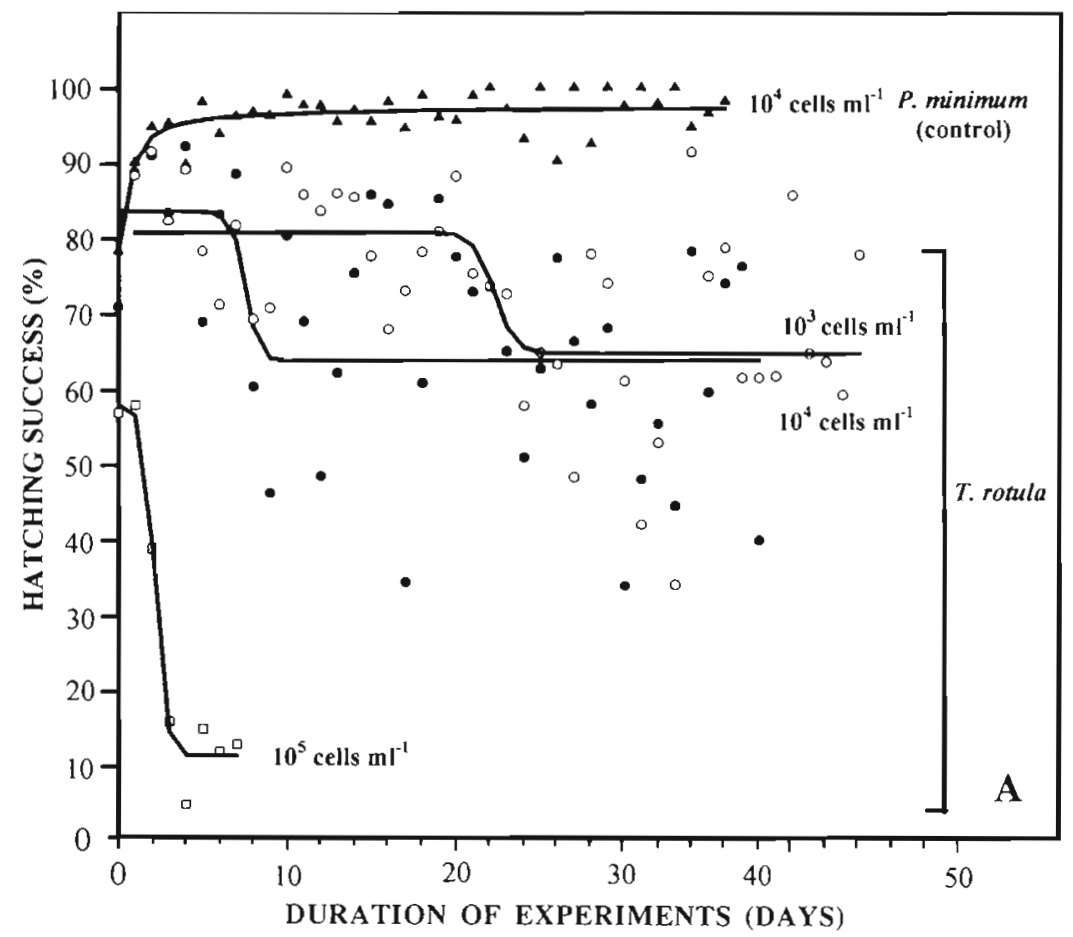

In the following series of experiments, batches of females were fed TR at 3 different concentrations. The 3 sets of experiments, corresponding to $10^{4}, 10^{3}$ and $10^{2}$ cells $\mathrm{ml}^{-1}$ in diets, were conducted for 37,45 and $40 \mathrm{~d}$, respectively. The results presented for TR at $10^{5}$ cells $\mathrm{ml}^{-1}$, obtained during an $8 \mathrm{~d}$ incubation period, are borrowed from Poulet et al. (1994). The relationship between hatching success, time, and food concentration presented the same pattern (Fig. 3A). Eq. (2) was used to fit hatching values, but explained a significant part of the variance only at food concentrations varying from $10^{5}$ to $10^{3}$ cells $\mathrm{ml}^{-1}$ (Table 1 ). At $10^{2}$ cells $\mathrm{ml}^{-1}$, TR modified hatching success (Fig. 3B). However, the data could not be fitted by Eq. (2), since neither $r^{2}$ nor $\chi^{2}$ were significant. At such low diatom concentrations, the extremely unstable daily variations of hatching success were not comparable to controls (Fig. 3A.), showing a $60 \%$ amplitude between maximum and minimum values recorded over the $40 \mathrm{~d}$ incubation period. As shown before, the highest level of instability was observed in the second half of the experiments (Fig. 3). At food levels $\leq 10^{4}$ cells $\mathrm{ml}^{-1}$, the calculated range (a) for hatching was only 16 to $20 \%$, while the lower threshold (d) was similar (ca 64\%). The lag time (c), again, varied in the opposite direction of diatom concentration (Table 1).

Hatching success was inversely related to the quantity of the diatom PT ingested as determined by the average daily production of fecal pellets (Fig. 4). The relation between \% hatching $(Y)$ and average number of fecal pellets produced per female $(X)$ produced at each food concentration is described by the linear regression:

$$
\begin{gathered}
Y_{3}=89.06-4.34 X \\
\left(\mathrm{r}^{2}=0.986, \mathrm{n}=4, \alpha=0.05\right)
\end{gathered}
$$

This relation is described for PT only, since fecal pellet production was measured only with TR at $10^{4}$ cells $\mathrm{ml}^{-1}$.

Differences in hatching success in relation to carbon food concentration $\left(X_{c}\right)$ are shown in Fig. 5 and are given by the following equation:

$$
\begin{gathered}
Y_{4}=123.5-25 \log X_{c} \\
\left(\mathrm{r}^{2}=0.987, \mathrm{n}=7, \alpha=0.05\right)
\end{gathered}
$$

For the same algal concentrations (ca $10^{4}$ cells $\mathrm{ml}^{-1}$ ) food stock differed in terms of carbon provided in the diet. PT was the poorest of the 3 algae. PM and TR 


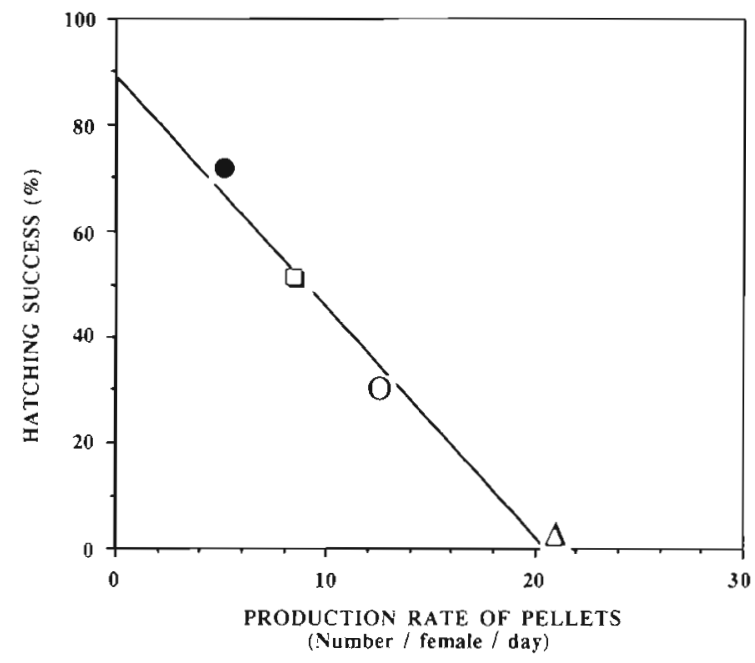

Fig. 4. Relationship between mean daily fecal pellet production and hatching success in Calanus helgolandicus fed 4 concentrations of the diatom PT: $10^{3}(\bullet), 10^{4}(0), 10^{5}(0)$ and $10^{6}$ $(\Delta)$ cells $\mathrm{ml}^{-1}$ Each data point is the average of 3 experiments

were 20 to 40 times higher in terms of carbon per cell, inducing much higher egg production rates. However, carbon cell content was not related to egg viability. Hatching success with PT and TR was similar but much lower than with the dinoflagellate diet (Fig. 5).

The complete data set of values, corresponding to laboratory observations, was used to model the relationship between the reproductive response of $\mathrm{Ca}$ lanus helgolandicus and the diatom concentration in the diets. Both the lower threshold $\left(Y_{5}\right)$ for hatching success and the time lag $\left(Y_{6}\right)$ (corresponding to para-

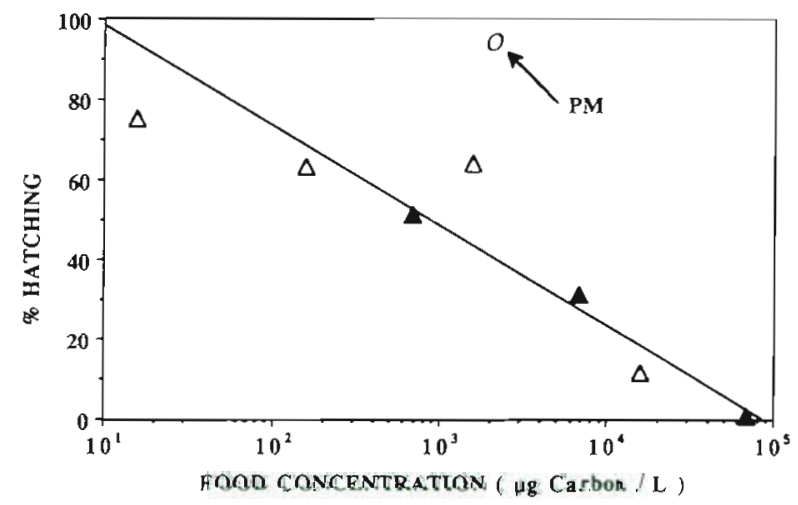

Fig. 5. Calanus helgolandicus. Comparison of the effect of carbon content of PM, PT and TR on hatching success. Hatching values are means of triplucate expenments (see Table 1). Combined values for carbon concentration in containers for each diatom diet are calculated for PT $(\mathbf{\Delta})$ in the $10^{4}$ to $10^{6}$ cells $\mathrm{ml}^{-1}$ range, and for TR $(\Delta)$ in the $10^{3}$ to $10^{5}$ cells $\mathrm{ml}^{-1}$ range. $O$ : Mean values for the dinoflagellate diet $P M$ in controls (ca $10^{4}$ cells $\mathrm{ml}^{-1}$ )
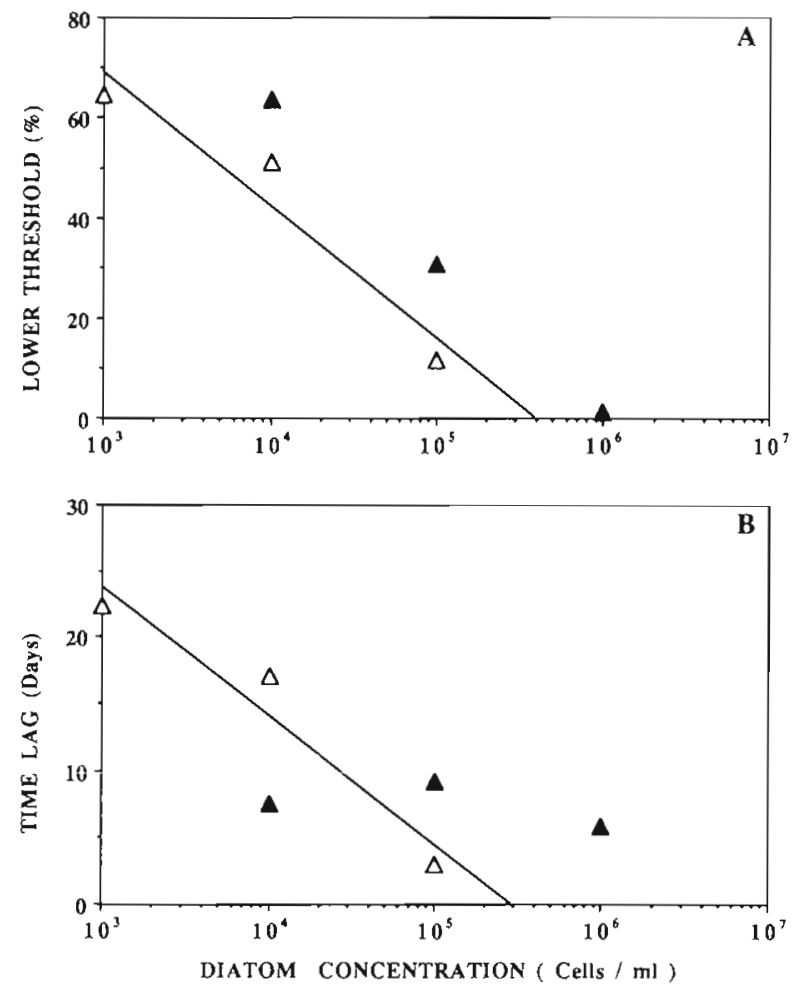

Fig. 6. Functional response of Calanus helgolandicus to diatom concentrations. (A) Variation of the lower threshold of hatching success corresponding to parameter $d$ calculated in Eq. (2). Linear regression equation is given in Eq. (5) (see text). (B) Variation of the time lag preceding maximum rate of inhibition of hatching, corresponding to parameter $C$ in Eq. (2). Linear regression is given in Eq. (6) (see text). Each data point is the sum of all experiments achieved with PT ( $\mathbf{\Delta})$ and $\operatorname{TR}(\Delta)$, respectively (see Table 1 )

meters $d$ and $c_{1}$ respectively, in Table 1) are decreasing functions of the diatom concentration $\left(D_{C}\right.$, expressed in cells $\mathrm{ml}^{-1}$; Fig. 6). A linear regression:

$$
\begin{gathered}
Y_{5}=149-27 \log D_{c} \\
\left(\mathrm{r}^{2}=0.926, \mathrm{n}=6, \alpha=0.05\right)
\end{gathered}
$$

fitted these 2 variables (Fig. 6A). The time lag was significantly and inversely correlated to the diatom concentration $\left(D_{c}\right)$, as shown in Fig. 6 and by the linear equation:

$$
\begin{gathered}
Y_{5}=52.7-9.65 \log D_{c} \\
\left(\mathrm{r}^{2}=0.934, \mathrm{n}=6, \alpha=0.05\right)
\end{gathered}
$$

\section{DISCUSSION}

Food availability is an important factor affecting growth and fecundity in copepods (Bottrell et al. 1976 , Ban 1994). Algae widely cited as high quality diets do not always provide adequate food quality for copepod 
fecundity (i.e. Chen \& Folt 1993), or egg viability (Poulet et al. 1994). Here, the 3 algal species induced different reproductive responses in terms of egg production. However, the specific maximum egg production rate in Calanus helgolandicus, ca 60 eggs female ${ }^{-1} d^{-1}$ (Marshall \& Orr 1952), was never reached when females were fed the diatoms ad libitum (Fig. 1A-C). Even during diatom blooms occurring in the English Channel, offshore of Roscoff or Plymouth, fecundity in the field was generally below maximum rate (Guisande \& Harris 1995, Laabir et al. 1995b), meaning that under natural food conditions or with PT and TR diets, females were mostly food limited. When fecundity at the same algal concentration was compared (ca $10^{4}$ cells $\mathrm{ml}^{-1}$; Fig. $1 \mathrm{~A}-\mathrm{C}$ ), highest values were obtained with the dinoflagellate PM as compared to the 2 diatom diets. Carbon concentrations explained differences in fecundity, i.e. the higher the carbon content in food, the greater the number of eggs produced (i.e. Checkley 1980, Guisande \& Harris 1995), but did not explain the differences in hatching success. PM was high in carbon content per cell and induced high egg viability (Fig. 5). In contrast, the relationship between hatching success and diatom concentration in terms of carbon, calculated and combined for PT and TR (Fig. 5) and given in Eq. (4), shows that egg viability was inversely correlated with the amount of diatom food carbon. Furthermore, Guisande \& Harris (1995) have shown that the size of eggs released by female $C$. helgolandicus fed the diatom Thalassiosira weissflogii over $5 \mathrm{~d}$, at concentrations ranging between 50 and $500 \mu \mathrm{g} \mathrm{C} \mathrm{l}^{-1}$, varied between 160 and $180 \mu \mathrm{m}$. A similar range of variations was observed offshore of Roscoff over 6 mo, from March to August 1993 (Poulet et al. 1995). However, we found that hatching success was not significantly correlated to any biometric egg parameters within this specific egg size range, which is in contradiction with the results reported by Guisande \& Harris (1995). We also have observed (M. Laabir, S. A. Poulet, R. P. Harris, S. W. Pond, A. Cueff, R. N. Head, A. Ianora unpubl.) that 40 to $80 \%$ inhibition of hatching was induced by $T$. weissflogii in the range of $10^{3}$ to $10^{4}$ cells $\mathrm{ml}^{-1}$. However, viability of eggs remained close to $100 \%$ during the first $10 \mathrm{~d}$ of incubation, and then decreased sharply $12 \mathrm{~d}$ after the start of feeding by female $C$. helgolandicus. In this case, our results are consistant with Guisande \& Harris' (1995) observations, showing that $5 \mathrm{~d}$ was not enough to induce inhibition of hatching, when concentrations of diatoms were $\leq 10^{4}$ cells $\mathrm{ml}^{-1}$ (Figs. $2 \& 3$ ).

The results of the present study indicate that inhibition of copepod embryonic development is diatom density-dependent. Highest diatom densities $\left(10^{6}\right.$ cells $\mathrm{ml}^{-1}$ ) with PT and TR induced $100 \%$ egg mortality within 5 to $10 \mathrm{~d}$. By progressively lowering the concentration of diatom cells fed to copepods, mortality was relaxed to $70 \%\left(10^{5}\right.$ cells $\left.\mathrm{ml}^{-1}\right)$ and $50 \%\left(10^{4}\right.$ cells $\left.\mathrm{ml}^{-1}\right)$ within 12 and $18 \mathrm{~d}$, respectively. The same pattern was observed with the 2 diatoms. In the case of TR, lower concentrations of cells, resembling in situ levels, were tested $\left(10^{2}\right.$ and $10^{3}$ cells $\left.\mathrm{ml}^{-1}\right)$, and average mortality decreased to $35 \%$ within $24 \mathrm{~d}$. The dinoflagellate PM induced no deleterious effects on embryonic development, confirming previous results with this alga (e.g. Poulet et al. 1994)

The pattern of inhibition for both diatom species, at cell concentrations $\geq 10^{3}$ cells $\mathrm{ml}^{-1}$, was basically the same and was best described by a sigmoid-shaped curve. There was an initial period of latency which lasted between 2 and 20 d, depending on the diatom concentrations (Table 1 ). This was followed by a rapid diminution in hatching success, over 1 to $3 \mathrm{~d}$, until values were stabilized and reached a lower threshold level of hatching success, which generally lasted until the end of incubations. The higher the concentration of diatoms, the shorter the lag time to reduce hatching (Figs. 2, $3 \& 6 \mathrm{~B}$ ), indicating that the process was food density-dependent. At very high concentrations $\left(10^{6}\right.$ cells $\left.\mathrm{ml}^{-1}\right)$, this period was very brief. At lower concentrations $\left(10^{3}\right.$ cells $\left.\mathrm{ml}^{-1}\right)$, corresponding to natural phytoplankton bloom situations, this period lasted much longer $(20 \mathrm{~d})$, suggesting a longer lag time before inhibition under natural in situ conditions (Laabir et al. 1995b). The link between the quantity of diatoms ingested and the accumulation of inhibitors in the gonads was indirectly confirmed by fecal pellets counts, indicating a relation between feeding and inhibition of embryonic development (Fig. 4).

Also, the lower threshold level $(d)$ of hatching depended on the concentration of diatom cells fed upon (Fig. 6A). The greater the number of cells, the greater the inhibition, and vice versa. In all cases, minimum values observed for hatching were below the calculated lower threshold (Figs. 2 \& 3). At low concentrations (ca $10^{2}$ to $10^{3}$ cells $\mathrm{ml}^{-1}$ ) the amplitude of variations in hatching success was very high, especially in the second half of incubations (Fig. 3A, B). Interestingly, at $\leq 10^{4}$ cells $\mathrm{ml}^{-1}$, inhibition of development never reached $100 \%$, indicating that diatom inhibitors may have partially been metabolized by digestive enzymes so that they never accumulated in the gonads beyond a certain level. This partially contradicts our previous assumption that inhibitory compounds are passively accumulated in the gonads (Poulet et al. 1994). Apparently, copepods may break down inhibitory products as long as diatom concentrations do not exceed certain levels (i.e. bloom conditions, patchy diatom distribution). This is also supported by the fact that variability in hatching success 
increases as the diatom concentration in the diet decreases (Fig. 3B).

We believe that differences in hatching success between diatom and non-diatom diets are related to the presence of inhibitory compounds blocking copepod embryogenesis, as discussed in several of our previous works (Poulet et al. 1994, 1995, Laabir et al. 1995b). Evidence of the presence of such compounds is accumulating To date, it has been demonstrated that:

(1) several diatom species block hatching success of eggs (lanora et al. 1995, Uye 1996),

(2) hatching inhibition has been induced in several copepod species (Ianora \& Poulet 1993, Poulet et al. 1994, Miralto et al. 1995, lanora et al. 1996, Uye 1996),

(3) the inhibitory compound is contained within the diatom cells and not in bacteria associated with diatom cultures (Ianora et al. 1996),

(4) this effect is not due to anoxia during incubation of eggs (Miralto et al. 1995),

(5) inhibition is reversible when a diatom diet is substituted with a dinoflagellate diet (Laabir et al. 1995b),

(6) nauplii are also affected by diatom inhibitors (Poulet et al. 1995)

In the present study we also show, for the first time, that the lower the diatom concentrations fed upon, the longer the time lag to induce blockage of egg development and the higher the amplitude between daily pulses of low and high hatching rates.

The question of the inhibitory effect of diatoms on the reproductive biology of copepods casts a shadow of doubt on the role of predation as the major factor influencing changes in plankton production in aquatic systems. For many years, this idea has not been challenged simply because few studies have been devoted to the physiology of copepod reproduction and development. Mortality of eggs and early developmental stages have been calculated in the field on the basis of differences in recruitment rates between eggs and older stage stocks (i.e. Edmondson et al. 1962, Liang et al. 1994). However, to date the evidence supporting the hypothesis that predation is the main cause of mortality is mainly speculative. Several studies indicate that natural mortality due to inhibitory compounds (Poulet et al. 1994), poor egg quality (Jónasdóttir 1994, Guisande \& Harris 1995), disease (Ianora et al. 1987) and pollution (Toudal \& Riisgard 1987, Kjørsvik et al. 1990) can account for a large fraction of the total loss to recruitment. More attention should therefore be directed to understanding the causes of low hatching success since embryonic mortality due to 'physiological' causes can be opportunely quantified in the laboratory. In the long run, such studies will allow for a better comprehension of the process regulating recruitment rates and plankton production at sea.
Acknowledgements. We sincerely thank Drs S. I. L ve and D. Vaulot for their help and suggestions in the final preparation of the manuscript. We also thank the crew of the RV 'Mysis' for their help and assistance at sea.

\section{LITERATURE CITED}

Ban SH (1994) Effect of temperature and food concentration on post-embryonic development, egg production and adult body size of the calanoid copopod Eurytemora affinis. J Plankton Res 16:721-735

Bottrell HH, Duncan A, Gliwics ZM, Grygierek E, Herzig A (1976) A review of some problem in zooplankton production. Norw J Zool 24:419-456

Checkley DM (1980) Food limitation of egg production by a marine planktonic copepod in the sea of southern California. Limnol Oceanogr 25:991-998

Chen WH, Folt CL (1993) Measures of food quality as demographic predictors in freshwater copepods. J Plankton Res 15:1247-1261

Confer JL, Cooley JM (1977) Copepod instar survival and predation by zooplankton. J Fish Res Bd Can 34:703-706

Dagg MJ (1977) Some eftects of patchy tood environments on copepods. Limnol Oceanogr 22:99-107

Edmondson NT, Comita GW, Anderson GC (1962) Reproductive rate of copepods in nature and its relation to phytoplankton population. Ecology 43:625-634

Fox E, Shotton K (1995) Transforms and nonlinear regression. Jandel Screntific, San Rafael, CA

Guillard RRL, Ryther JH (1962) Studies of marine planktonic diatoms. I. Cyclotella nana Hustedt and Detonula confervacea (Cleve) Gran. Can J Microbiol 8:229-239

Guisande C, Harris RP (1995) Effect of total organic content of eggs on hatching success and naupliar survival in the copepod Calanus helgolandicus. Limnol Oceanogr 40 . $476-482$

Ianora A, Mazzochi MG, Grottoli R (1992) Seasonal fluctuations in fecundity and hatching success in the planktonic copepod Centropages typicus. J Plankton Res 14 $1483-1494$

Ianora A, Mazzochi MG, Scotto Di Carlo B (1987) Impact of parasitism and intersexuality on Mediterranean populations of Paracalanus parvus (Copepoda: Calanoida). Dis Aquat Org 3:29-36

Ianora A, Poulet SA (1993) Egg viability in the copepod Temora stylifera. Limnol Oceanogr 38:1615-1626

Ianora A, Poulet SA, Miralto A. (1995) A comparative study of the inhibitory effect of diatoms on the reproductive biology of the copepod Temora stylifera. Mar Biol 121:533-539

Ianora A, Poulet SA, Miralto A. Grottoli R (1996) The diatom Thalassiosira rotula affects reproductive success in the copepod Acartia clausi. Mar Biol 125:279-286

Jonasdóttir SH (1994) Effects of food quality on the reproductive success of Acartia tonsa and Acartia hudsonica: laboratory observations. Mar Biol 121:67-81

Keller MD, Selvin RC, Claus W, Guillard RRL (1987) Medıa for the culture of oceanic ultraphytoplankton. J Phycol 23: $633-638$

Kiørboe T, Mohlenberg F, Tiselıs P (1988) Propagation of planktonic copepods: production and mortality of eggs. Hydrobiol 1.67/168:219-225

Kiørboe T, Nielsen TG (1994) Regulation of zooplankton biomass and production in a temperate, coastal ecosystem. I. Copepods. Limnol Oceanogr 39:493-507

Kjørsvik E, Mangor-Jensen A. Holmefjord I (1990) Egg quality in fishes. Adv Mar Biol 26:71-113 
Laabir M, Poulet SA, lanora A. (1995a) Measuring production and viability of eggs in Calanus helgolandicus. J Plankton Res 17:1125-1.142

Laabir M, Poulet SA, Ianora A, Miralto A, Cueff A (1995b) Reproductive response of Calanus helgolandicus. 1I. In situ inhibition of embryonic development. Mar Ecol Prog Ser 129:97-105

Liang D, Uye Sl, Onbe T (1994) Production and loss of eggs in the calanold copepod Centropages abdominalis Sato in Fukuyama Harbor, the Inland Sea of Japan. Bull Plankton Soc Japan 41:131-142

Marshall SM, Orr AP (1952) On the biology of Calanus finmarchicus. VII. Factors affectıng egg production. J Mar Biol Ass UK 30:527-547

Miralto A, lanora A, Poulet SA (1995) Food type induces different reproductive responses in the copepod Centropages typicus. J Plankton Res 17:1521-1534

Peterson WT, Kimmerer WJ (1994) Processes controlling recruitment of the marine calanoid copepod Temora longicornus in Long Island Sound: egg production, egg mortality, and cohort survival rates. Limnol Oceanogr 39:1594-1605

Poulet SA, Ianora A, Miralto A, Meijer L (1994) Do diatoms arrest embryonic development in copepods? Mar Ecol Prog Ser 111:79-86

Poulet SA, Laabir M, Ianora A, Miralto A (1995) Reproductive response of Calanus helgolandicus. I. Abnormal embry-

This article was submitted to the editor onic and naupliar development. Mar Ecol Prog Ser 129 $85-95$

Santer B (1994) Influence of food type and concentration on the development of Eudiaptomus gracilis and implications for interactions between calanoid and cyclopoid copepods. Arch Hydrobiol 131:141-159

Saunders B (1991) Comparative study of the biochemical composition of selected species of phytoplankton in the Plymouth culture collection. PML report. Plymouth Marine Laboratory

Sournia A, Birrien JL (1995) La série océanographique còtière de Roscoff (Manche occidentale) de 1985 à 1992. Cah Biol Mar 36:1-8

Toudal K, Risgard HU (1987) Acute and sublethal effects of cadmium on ingestion, egg production and life-cycle development in the copepod Acartia tonsa. Mar Ecol Prog Ser 37:141-146

Uye SI (1996) Induction of reproductive failure in the planktonic copepod Calanus pacificus by diatoms. Mar Ecol Prog Ser 133:89-97

Wilkinson L, Hill MA, Miceli S, Birkenbeuel G, Vang E (1992) Systat for Windows, version 5. Systal, Inc., Evanston, IL

Williamson CE, Butler NM, Forcina L (1985) Food limitation in naupliar and adult Diaptomus pallidus. Limnol Oceanogr $30: 1283-1290$

Manuscript first recelved: February 13, 1996

Revised version accepted: August 14, 1996 